\title{
A NEW RUSSIAN NATIONAL DEFENCE CONTROL SYSTEM: REFORM OR IMITATION?
}

\author{
V.Tsymbal, V.Zatsepin
}

One year has passed since the Russian Defense Ministry established the National Defense Control Center, similar to that of the EMERCOM. According to the point of view prevailing in mass media, the NDCC has since then proved efficient command and control center for military training and day-to-day operations. However, the NDCC is facing a marked trend towards substituting official accounting and statistics with video camera recordings, which questions the concept behind it.

One year has passed in April since the Russian National Defense Control Center (NDCC) was put into operation in test mode since April 2014 and in regular mode since 1 December ${ }^{1}$. The NDCC is comprised of three subordinate control centers, namely the Strategic Nuclear Forces (SNF) Control Center, the Combat Control Center which manages the rest of the Armed Forces, and other bodies and agencies within the military and security establishment, and the Daily Operations Control Center which coordinates logistics and civil agencies. This is what differs the NDCC from the existing General Staff Command Center which only controls the Armed Forces.

According to the data provided by the Defense Ministry Press and Information Office, as well as the articles written by journalists who visited the NDCC ${ }^{2}$, the specific feature of its day-to-day operations "is that a bottom-up 'stem' structure has been established at the federal, regional, territorial and local levels, which is designed to provide ongoing monitoring, real time analysis of the situation and prepare proposals to the higher command on top-priority measures in case of emergency or crisis situations". This is based on cutting edge scientific and technical achievements in informatics, telecommunications, computer science and control theory.

Following is what full general Gerasimov told journalists about his duties in the NDCC: "The general on duty reports 20-25 times a day on a variety of issues to me as Chief of the General Staff. Especially when it comes to deviations of any kind. Consequently, I make decisions myself or report to the Defense Minister for approval of proposals. At the same time, it is not that the general on duty just reports the situation, he, most importantly, makes conclusions and substantiated proposals which require approval or otherwise" ${ }^{\prime 3}$.

1 Nikolsky A. The National Defense Control Center has been put into operation // Vedomosti. 2 December 2014.

2 Gavrilov Y. The order will come from the NDCC // Rossyiskaya Gazeta. 27 October 2014.

3 Hereinafter the quotations are taken from the announcement of the briefing held on 1 November 2014 by Chief of the General Staff Valeriy Gerazimov. URL: http://function.mil.ru/news_page/
"Such a unit helps making prompt decisions to respond adequately, whether it comes to facing unfriendly actions against sovereignty of Russia or running behind the schedule of a military construction project. The established mechanism allows military control bodies, executive power bodies and local government bodies to be engaged as soon as possible to jointly implement the decisions made". Thereupon, "in accordance with the National Defense Plan, 52 federal executive bodies and three organizations (public corporations) have their own defense tasks both in peacetime and wartime" ${ }^{\prime \prime}$. Neither does the NDCC substitute nor duplicate the functions of headquarters and military command and control bodies. There is one thing that matters most: "at all levels there is summarized and updated information on the composition, state, nature of actions of troops (forces), their well-being and readiness to accomplish the tasks". And, one more thing: "Apart from the constant readiness to make proposals on responding to crisis situations, the NDCC and its on-site units provide headquarters and military control bodies with information required for current and long-term planning, preparing and making decisions, communicating such decisions to the troops (forces), and follow-up". The Chief of the General Staff put a special emphasis on that "the composition of operations duty shifts and the NDCC functions remain the same in case of switching from peacetime to wartime. It is the volume of information, information processing intensity and preparation of the materials required for reporting that are to be changed. In other words, the tried-and-tested and up-and-running interactions and algorithms are kept intact under any conditions".

Back then, when the Defense Minister announced NDCC establishment plans, he said the following: "This

country/more.htm?id=11998309@egNews (date of access: 01.11.2014).

4 Other data report about the exchange of information with 78 federal executive bodies. See Vladykin O. Putin: The Russian Armed Forces must have better equipment than foreign ones // Nezavisimaya Gazeta (Internet version). 20 December 2014. 
is a deeply integrated system designed to control the Armed Forces, similar to a modern Commander-inChief Headquarters. This is our brain" ${ }^{1}$. Such a unit "is a complementary factor deterring aggression against Russia", the Chief of the General Staff added.

The NDCC is considered as having proved efficient during a large-scale strategic command-and-staff training exercise, "Vostok-2014", held on 19 thru 26 September 2014. "Round-the-clock monitoring of the exercise, it was clear when and how a given echelon was performing"2, said the Main Operations Directorate Chief of the General Staff. Last year, on the eve of Victory Day, the President of Russia held in the NDCC an Armed Forces command-and-control training. The invited leaders of the Collective Security Treaty Organization (CSTO) member states - Belarus, Armenia, Kyrgyzstan and Tajikistan - were given an opportunity to watch and assess the training which was intended to check the entire command and control system, the reliability of transmission of training orders and signals in the military districts, command centers of troops and military units, the Strategic Rocket Forces, Aerospace Defense Forces, all the way to the Long Range Aviation Command.

A special emphasis should be placed on the developers and creators of the new NDCC. The NDCC information and communication systems are integrated by RTI Sistmey, a concern owned by AFC Sistema. It is relevant from the military and economic viewpoint that the concern is the largest private enterprise contracted by the defense ministry. The concern supplies radar systems as part of the missile warning system (SPRN), and other one-of-a-kind powerful radar systems. The concern was selected for establishing the NDCC because RTI Sistemy had already been successfully engaged in developing the National Emergency Management Center for the EMERCOM (Russia's Emergencies Ministry). However, the NDCC scope of works is by far greater, as it requires much more data array to be processed and the NDCC survivability specific requirements to be met. The NDCC development cost, including the infrastructure outside Moscow, is more than Rb 20bn worth, while the contract with RTI Sistemy is a few billions worth, according to mass media ${ }^{3}$.

It is obvious that the NDCC development was chiefly based on applying exclusively domestically developed

1 The Russian National Defense Control Center begins to operate at full capacity. URL: http://function.mil.ru/news_page/country/ more.htm?id=12002229@egNews (date of access: 01.12.2014). 2 Ibid.

3 Nikolsky A. AFC Sistema will work on the infrastructure of the Defense Ministry's NDCC // Vedomosti website. 14 January $2014 .$. URL: http://www.vedomosti.ru/newsline/news/21312851/podkontrolnaya-sisteme-kompaniya-obespechit-infrastrukturu (date of access: 17.09.2014). technologies, because the NDCC plays an important role, particularly in the context of import substitution. All of the hardware and software involved are report-

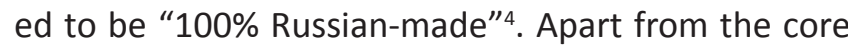
defense activity, the NDCC will be involved in monitoring what's going on at enterprises operating in the military-industrial complex (MIC), warehouses, military construction sites. About 700 video cameras will be mounted at more than 500 enterprises. The NDCC will be analyzing video recordings six times a day.

The establishment of a new public administration system required many bodies to be reorganized and totally upgraded. The NDCC employs "professionally trained operations duty officers at all, tactical to strategic, command levels, pulling a 24-hour alert duty in special premises equipped with cutting-edge means of communication and computerization. They monitor all areas of activities both inside the Armed Forces and across the entire Russian military establishment regarding the implementation of the National Defense Plan"5.

The efforts of the Defense Ministry Press and Information Office resulted in quite a positive image of the NDCC in domestic mass media in the past year, which has increasingly been applied for more tasks including military-diplomatic and anti-corruption ones.

Therefore, the Defense Ministry senior management considered it necessary to arrange for a visit of foreign military diplomats to the NDCC on 21 March in order to resolve the concerns of Russia's neighboring states about a recent sudden large-scale combat readiness test held between 16 and 21 March 2015 of the Northern Fleet and certain units in the Western Military District ${ }^{6}$. Furthermore, it was reported on 1 April that Deputy Prime Minister Dmitry Rogozin had given an order to prepare within three days a set of issues to be controlled by NDCC operations duty officers regarding the corruption-hit "Vostochny" construction project, a new Russian cosmodrome in the Amur Region?.

Is the defense control is as good as it is being painted by spokesmen representing departmental interests?

Regretfully, the above described way of developing a national defense control system which, owing

\footnotetext{
4 See "The Russian National Defense Control Center begins...". 5 See Gerasimov's briefing held on 1 November 2014. 6 The Russian National Defense Control Center was visited for the first time by more than 100 foreign defense attaches. URL: http:// function.mil.ru/news_page/country/more.htm?id=12011147@ egNews (date of access: 21.03.2015).

7 The Armed Forces "brain center" will be engaged in monitoring of the situation with "Vostochny" // RIA Novosti. 1 April 2015. URL: http://ria.ru/defense_safety/20150401/1055850768.html (date of access: 01.04.2015).
} 
to the Defense Ministry press, can be described as "multimedia"1, is seriously alarming.

The Defense Ministry senior management's achievements in making transparent collegiums, teleconferences and the so-called single days of accepting defense-oriented products, cannot make up for serious problems facing the Defense Ministry with regard to both property units (the 2013 inventory hasn't been completed yet) ${ }^{2}$ and utility costs ( $80 \%$ of the required 135,000 water, heat and electricity meters have been mounted) ${ }^{3}$.

Despite the Defense Ministry's major effort to streamline the accounting and departmental statistics, the NDCC has failed to enhance the quality of data which the Defense Ministry relies upon while making progress reports and work plans. As a result, for example, доля advanced samples in Air Force and Navy in the announced plan for 2015 (33\% and 51\%, respectively) ${ }^{4}$ appeared to be less than those achieved two years ago (42\% and 52\% in 2013) $)^{5}$. This indeed can be explained rationally by accelerated depreciation

1 Grozny O. The Armed Forces in plain sight // Krasnaya Zvezda. 27 March 2015. (No. 52). P. 16.

2 Russia's Defense Ministry executes title certificates to more than 200,000 real property units. URL: http://function.mil.ru/ news_page/country/more.htm?id=11996845@egNews (date of access: 22.10.2014).

3 Semenov D. A military budget without secrets // Krasnaya Zvezda. 7 March (No. 39). p.p. 1-2.

4 Vladykin O. Putin: The Russian Armed Forces must have better equipment than foreign ones // Nezavisimaya Gazeta (Internet version). 20 December 2014. URL: http://www. ng.ru/armies/2014-12-20/100_collegium.html (date of access: 20.12.2014).

5 The 2013report [Russia's Defense Ministry]. URL: http://mil. ru/files/files/result2013/index.html (date of access: 22.01.2014). of obsolete equipment, however, the unprecedented acceleration of the state defense contract volume raises unavoidable questions concerning both the quality of planning and the effectiveness of federal budget spending. The foregoing can lead to a conclusion that the NDCC super-computers were running free, just heating up the air, during the first year of operation.

Russian nationals have already learned about efficient utilization of video cameras to monitor the construction of new houses for those lost their houses from the fire in summer 2010 and the voting at the elections in 2011 and 2012, that's why they can hardly see any reason whatsoever in mounting video cameras at the assembly shop in a defense plant or cosmodrome construction site - video cameras cannot substitute military representatives and inspectors from the Federal Financial Monitoring Service or the Chamber of Accounts.

Although very comfortable conditions have been created in the NDCC for government and military officials in noteworthy multitiered boxes similar to those in theaters where - as is known - there is nothing more dangerous than fire. A fire broke out for the first time on 28 January 2015 in the NDCC - 150 persons were evacuated from the building after construction materials took fire at a flight of stairway of about 50 square meters ${ }^{6}$. Therefore, the reliability of the new national defense control system has been found to be disputable.

6 About 150 persons evacuated because of fire in the building of Russia's Defense Ministry // RIA Novosti. 28 January 2015. URL: http://mil.ru/files/files/result2013/index.html (date of access: 28.01.2015). 